\title{
Saphenous vein graft patency and fountain of youth
}

\author{
Paul Kurlansky, MD
}

\author{
From the Columbia University College of Physicians and Surgeons, New York, NY \\ Disclosures: Author has nothing to disclose with regard to commercial support. \\ Received for publication March 22, 2017; accepted for publication March 23, 2017; available ahead of print April \\ 26, 2017. \\ Address for reprints: Paul Kurlansky, MD, Black Building 210, 650 West 168th St, New York, NY 10032 (E-mail: \\ pk2245@cumc.columbia.edu) \\ J Thorac Cardiovasc Surg 2017;154:455-6 \\ $0022-5223 / \$ 36.00$ \\ Copyright $(2017$ by The American Association for Thoracic Surgery \\ http://dx.doi.org/10.1016/j.jtcvs.2017.03.112
}

Little question remains regarding the superior patency of the left internal thoracic artery (LITA) graft compared with the saphenous vein graft (SVG) in coronary bypass surgery. All current guidelines support the use of the LITA for bypassing the left anterior descending coronary artery, based on sound experimental and clinical evidence. ${ }^{1-3}$ The morphologic and physiologic substrates for internal thoracic artery patency, as well as the pathophysiology of SVG failure, have been well described. ${ }^{4,5}$

Into this arena enters a provocative report by Samano and colleagues, ${ }^{6}$ demonstrating SVG patency that rivals that of the LITA: $95.6 \%$ at 6 years. Certainly the door is open for questions. Only 91 of 168 patients were available for study -34 had died and the remainder did not consent or were otherwise ineligible. Study was via computed tomography scan rather than angiography and grafts were judged to be patent or occluded, rather than the more nuanced Fitzgibbon approach. ${ }^{7}$ Those patients not studied tended to be older and to have a higher European System for Cardiac Operative Risk Evaluation, and therefore possibly more prone to graft occlusion (the authors present an interesting analysis suggesting otherwise). Perhaps symptomatic patients might be more likely to consent, yet $88.7 \%$ were angina free. Conversely, those more "health conscious" might be more eager for study; $84.5 \%$ of those scanned were taking aspirin, and $89.7 \%$ were taking statins. Likewise, perhaps the 34 patients

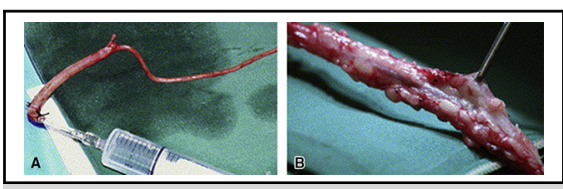

Saphenous vein: conventional and "no-touch" harvesting techniques.

Central Message

Despite a wealth of evidence documenting superior patency of arterial grafts, provocative evidence of SVG patency challenges our understanding of vein graft disease.

See Article page 457.

who died had graft occlusion. However, even if we were to assume that all 13 patients who died of cardiac causes had an occluded graft, we would have to postulate a $40 \%$ occlusion rate in the remaining nonstudied patients to bring the overall patency rate down to a more familiar $80 \% .^{8}$ Given the $93.8 \%$ SVG patency of the non-left anterior descending grafts in the studied patients, such a hypothesis seems highly unlikely. The most plausible explanation is that the SVG patency for this group is considerably higher than generally reported. Even presuming surgical expertise and appropriate selection of generous outflow beds, these grafts are still subject to compliance mismatch, to increased shear stresses imposed by arterial pressures, and to the resultant cytokine activation, all of which predispose to hyperplasia and accelerated atherosclerosis. Hypothetical preservation of vasa vasorum is unlikely, because this explanation would postulate mediastinal revascularization of these tiny feeding vessels - a vasculogenic response that seems improbable at best. What we are left with is the absence of vascular trauma in conduit harvest and handling (Figure 1).
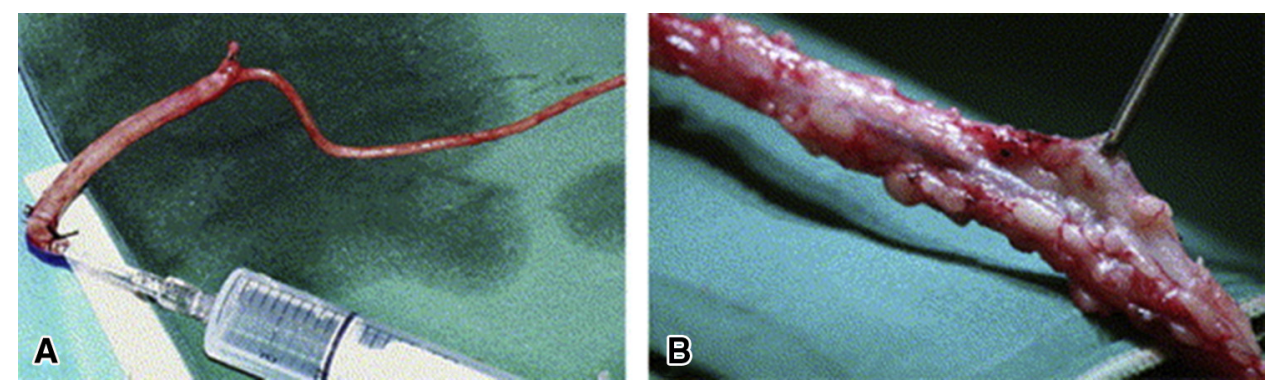

FIGURE 1. A, Saphenous vein harvested with the conventional technique. B, Saphenous vein harvested with the "no-touch" technique. Reprinted from Souza DS, Johansson B, Bojö L, Karlsson R, Geijer H, Filbey D, et al. Harvesting the saphenous vein with surrounding tissue for CABG provides long-term graft patency comparable to the left internal thoracic artery: results of a randomized longitudinal trial. J Thorac Cardiovasc Surg. 2006;132:373-8.e5. 
Although the mechanisms of SVG disease are multiple and complex, perhaps it is this initial endothelial or other vessel injury that is an essential initiating factor, whose absence is protective. Because the SVG remains the "workhorse" for the majority of the coronary artery bypass grafts currently performed worldwide, the potential implications of such a hypothesis are obvious and monumental. Although it is not without considerable reservation that I propose such an explanation, I am encouraged by the words of the Nobel zoologist Konrad Lorenz, who suggested "It is a good morning exercise for a research scientist to discard a pet hypothesis every day before breakfast. It keeps him young." 9

\section{References}

1. Kolh P, Windecker S, Alfonso F, Collet J-P, Cremer J, Falk V, et al. 2014402 ESC/EACTS Guidelines on myocardial revascularization: The Task Force on 403 Myocardial Revascularization of the European Society of Cardiology (ESC) and the 404 European Association for Cardio-Thoracic Surgery (EACTS)Developed with the 405 special contribution of the European Association of Percutaneous Cardiovascular 406 Interventions (EAPCI). Eur J Cardiothorac Surg. 2014;46:517-92.
2. Hillis LD, Smith PK, Anderson JL, Bittl JA, Bridges CR, Byrne JG, et al. 2011408 ACCF/AHA Guideline for Coronary Artery Bypass Graft Surgery: a report of the 409 American College of Cardiology Foundation/American Heart Association Task Force 410 on Practice Guidelines. Circulation. 2011;124:e652-735.

3. Aldea GS, Bakaeen FG, Pal J, Fremes S, Head SJ, Sabik J, et al. The Society of 420 Thoracic Surgeons Clinical Practice Guidelines on Arterial Conduits for Coronary 421 Artery Bypass Grafting. Ann Thorac Surg. 2016;101:801.

4. Kurlansky P. Multiple arterial grafting for coronary revascularization: "A guide for the perplexed" Trends Cardiovasc Med. 2016;26:616-23.

5. Harskamp RE, Lopes RD, Baisden CE, deWinter RJ, Alexander JH. Saphenous vein graft failure after coronary artery bypass surgery: pathophysiology, management and future directions. Ann Surg. 2013;257: 824-33.

6. Samano N, Geijer H, Bodin L, Arbeus M, Mannion J, Dashwood M, et al. The no-touch saphenous vein graft in elderly coronary bypass patients with multiple comorbidities is a promising conduit to substitute the left internal thoracic artery. J Thorac Cardiovasc Surg. 2017;154:457-66.e3.

7. Fitzgibbon GM, Kafka HP, Leach AJ, Keon WJ, Hooper GD, Burton JR. Coronary bypass graft fate and patient outcome: angiographic follow-up of 5065 grafts related to survival and reoperation in 1388 patients during 25 years. J Am Coll Cardiol. 1996;28:616-26.

8. Tatoulis J, Buxton BF, Fuller JA. Patencies of 2127 arterial to coronary conduits over 15 years. Ann Thorac Surg. 2004;77:93-101.

9. Lorenz K. BrainyQuote.com. Available at: https://www.brainyquote.com/quotes/ quotes/k/konradlore102428.html. Accessed April 20, 2017. 